\title{
Some Cultural Features of Vietnamese Personal Names
}

\author{
Thao, Le Thi Minh \& Thanh, Le Van \\ Hanoi Open University, Hanoi, Vietnam
}

\begin{abstract}
Personal name is not only the identification symbol for unique person, but it also contains the historic, traditional, cultural, social information of each person and certain ethnic or nation. Vietnamese personal names and the ways of naming reflect many features of Vietnamese culture. In this paper, the descriptive method has been used to display the features of Vietnamese personal names with the aim of showing the principle of naming in Vietnam especially some cultural features of Vietnamese names. As a result, readers can understand more about Vietnamese custom, habit and tradition relating to personal names
\end{abstract}

KEYWORD: cultural features; culture society; name; Vietnamese personal name

\section{INTRODUCTION}

Personal name is an important role in proper name system. It is not only the identification symbol for unique person, but it also contains the historic, traditional, cultural, social information of each person and certain ethnic or nation. Naming customs are various greatly from the different countries. In some cases they are very simple, but they are very complicated in many countries. In Vietnam, personal names are not only a significant sign to differentiate, but also a meaningful word... When parents name their children, they have to work hard on thinking, selecting how to name their babies beautifully and meaningfully. They hope their babies will get a lot of luck, success, good health etc. when they grow up. Name of a person can express a certain criterion, an attitude, sentiment of the name giver. A vulgar name will leave the bad impression on the other people; a beautiful name will be admired by others.

\section{ROLE OF PERSONAL NAMES}

Personal names play significant roles in racial, religious, gender, and ethnic distinction. Name usually sticks with a person all his life. The name offers the first nonverbal impression of the individual. People usually make assumptions of a person, upon seeing or hearing his names, such as his ethnic background. Names are important because people make judgments about a name before they will even meet the person.
As Pulgram [4] pointed out, personal names are connected to cultural phenomena such as personal and collective identity, social class distinctions, religious affiliation, positive and negative character traits, and practically every human virtue.

According to Trần Ngọc Thêm [8], personal names have five functions as follows:

- The function of distinction

- The function of sex distinction

- The function of aesthetics

- The protective function (health and safety)

- The social function (distinguishing between the rich and the poor)

Nowadays, in the modern society, the protective function and the social function are no longer necessary. They reflect the backwardness of people's material and spiritual life.

\section{THE INFLUENCE OF CULTURE ON VIETNAMESE PERSONAL NAMES}

\subsection{The principle of naming}

According to Lê Trung Hoa [2] and Trần Ngọc Thêm [6] the Vietnamese often use the following principles to name their children:

The principle of "shortness": First name should be in short form to be good for task of communication.

The principle of "avoiding namesake": First name should be chosen to be different from the other people' names so as to function a distinction well. 
The principle of "differentiating sex": The more modern society is, the higher the need of aesthetics is. So the names are also inclined to be good ideas and beautiful syllables.

\subsection{Some cultural features of Vietnamese personal name}

According to Dương Kỳ Đức [1], Vietnamese personal names have the following features:

Firstly, Vietnamese personal names reflect the religion of fertile culture of Vietnam (that is, honoring the growth of nature and people, expressing in the worship of males and female's genitals, receiving "nõ", "nường" graciously ...). According to this custom, the Vietnamese children's names as $\mathrm{Cu}$ (male's sex organ), Bòi (male's sex organ), Hĩm (female's sex organ)... are the sex organs of people.

Secondly, Vietnamese personal names reflect the religion of respecting nature.

Worshipping Tree Mother: Mẫu Thượng Thiên = Bà Trời (lady of Heaven), Mẫu Địa = Bà Đất (lady of land), Mẫu Thoải = Bà Nước (lady of water)...We have the names: Mây (cloud), Phong (win), Nguyệt (moon), Hằng (moon), Vũ (win), Tuyết (snow), Xuân (spring), Hạ (summer), Thu (autumn), Đông (winter)...

Worshipping animals and plants: deer, buffalo, toad, water bird, crocodile, God of Rice, Soul of Rice, Mother of Rice, areca palm tree, banyan-tree, rice tree, fig tree, mulberry tree...we have the names like: Hổ (tiger), Hùm (tiger), Sói (wolf), Trăn (python), Rồng (dragon), Dế (cricket), Ong (bee), Bướm (butter fly)...

Worshipping God: Thần Hoàng (God of the village), Thần Tản (God of Tản Viên)... the names like Bụt (Buddha), Phật (buddha), Tiên (fairy), Ngọc Hoàng (the King of Heaven).

Avoiding evils and ghosts: naming the bad names for not being caught by evils: Cứt (shit), Bùn (mud)...

Thirdly, Vietnamese personal names show the respect to agriculture, the main living source of the inhabitants of the region of wet rice.

The names relating to cereal: Lúa (rice), Ngô (corn), Khoai (potato), Sắn (cassava), Mì (wheat), Mạch (buckwheat)...

The names of vegetables: Cải (cabbage), Dền (amaranth), Bí (pumpkin buds), Húng (mint leaves)...

The names of animals in water environment: Rô (anabas), Mè (chub), Chép (carp), Trê (catfish), Ốc (snail), Cò (stork), Vạc (night heron)...

The names of tools of agriculture labor: Cày (plow), Bừa (hammer), Cuốc (hoe)...

The names of handicraft labor closed to agriculture: Kén (follicle), Sợi (fibre), Chỉ (thread), Vải (cloth), Lụa (slik)...
Fourthly, naming reflects the religion of venerating dead people (worshipping ancestors). According to culture style, Vietnamese people avoid taking the parents' or grandparents' names for offspring to prevent mentioning their names.

Fifthly, the philosophy of amalgamation or mixture expresses that the Vietnamese are not extreme; they do not totally disapprove of foreign things but approved the foreign factors. Sometimes, this philosophy is misunderstood as xenophobia, especially when it is excessively displayed. In personal names, it is shown in the Chinese and SinoChinese and Western names like: Thảo, Thúy, Hà, Ngọc, Tâm, Dũng, Trí, Anh, Tân, Noen, Lêna...

Sixthly, Vietnamese people always regard surnames more important than first names. People can change their first names, but it is certain that they rarely change their surnames (except for some special cases in the past: "Trần" dynasty, for example, forced the offspring of "Ly'" dynasty to change into the surname "Nguyễn". The offspring of "Trịnh Lords" had to change into the surname "Nguyễn" to avoid the revenge when "Trịnh" dynasty declined). If the Vietnamese change their surnames, they will be considered the rootless people. The Vietnamese people always respect the family, and undervalue the individuals. In the structure of Vietnamese personal names, which is shown very clearly, surnames reflect the family or the blood relationship and first names indicate the individuals. Therefore, surnames are placed before the first names.

However, culture style is not immutable, but always changeable. For example, for the last several decades of the twentieth century, the Vietnamese have been inclined to give up naming after pureVietnamese words, but they have been found using the Chinese or Sino-Chinese words to have beautiful content and sound harmony.

\section{CONCLUSION}

It can be said that personal name is one of the typical aspect of culture and society in every country. It plays an important role in formal and informal communication. Some cultural features of Vietnamese names have been presented in this paper. As a result, readers can understand more about Vietnamese custom, habit and tradition relating to personal names.

\section{REFERENCES}

[1] Dương Kỳ Đức. 1998. Văn hóa trong tên người Việt. Tạp chí Ngũ hoc trẻ 98:143-145.

[2] Lê Trung Hoa. 1992. Họ và tên người Việt Nam. NXB Khoa học Xã hội, Hanoi, Vietnam: 87-91. 
[3] Lê Trung Hoa. 1992. Cách đặt tên chính của người Việt (Kinh), Tiếng Việt và các ngôn ngũ dân tộc phía Nam. NXB Khoa học Xã hội, Hanoi, Vietnam: 112-124.

[4] Pulgram, e. 1954. Theory of names, London-New York: 78.

[5] Trần Ngọc Thêm. 1999. Cơ sở văn hóa Việt Nam. NXB Giáo dục, Hanoi, Vietnam: 86-88.
[6] Trần Ngọc Thêm. 1996. Tìm về bản sắc văn hóa Việt Nam. NXB Thành phố Hồ Chí Minh, Ho Chi Minh City, Vietnam: 34-50.

[7] Trần Ngọc Thêm. 1976. Về lược sử hiện tại và tương lai của tên riêng trong người Việt. Tạp chí dân tộc học số 3: $11-21$.

[8] Trần Ngọc Thêm. 1976. Về lịch sử hiện tại và tương lai của tên riêng người Việt. Tạp chí Ngôn ngũu 6: 68-72. 